OPEN

SUBJECT AREAS:

DISEASES

CYTOKINES

MODELLING

IMMUNITY

Received

25 March 2011

Accepted

16 May 2011

Published

15 July 2011

Correspondence and requests for materials should be addressed to

T.Z. (tzheng@jhmi.

edu)

\section{The Role of TSLP in IL-13-Induced Atopic March}

\author{
Zhou Zhu' , Min-Hee Oh' ${ }^{1}$ Jinho Yu', Yong Jun Liv'² \& Tao Zheng'
}

\begin{abstract}
'Division of Allergy \& Clinical Immunology, Department of Medicine, Johns Hopkins University School of Medicine, 5501 Hopkins Bayview Circle, 1 A-38, Baltimore, MD $21224,{ }^{2}$ Department of Immunology, The University of Texas MD Anderson Cancer Center, Houston, TX 77030
\end{abstract}

Although atopic dermatitis (AD) is the initial step of the "atopic march", a progression from AD to asthma, the underlying mechanism remains unknown. Selective expression of IL-13 in the skin of mice caused an AD phenotype resembling human $\mathrm{AD}$, and the disorder was associated with enhanced production of thymic stromal lymphopoietin (TSLP) in the AD skin with a systemic Th2 immunity. Here we show that IL-13 transgenic mice with $\mathrm{AD}$ had significantly enhanced lung inflammation, mucus hypersecretion, and airway hyperresponsiveness (AHR) when sensitized and challenged by allergen. In addition, the level of TSLP was significantly higher in acute $\mathrm{AD}$ than in chronic $\mathrm{AD}$. Furthermore, elimination of TSLP signaling significantly diminished the allergic asthma responses, immune cell production of Th2 cytokines (IL-4, IL-13), and serum IgE. These studies indicate that IL-13 induces AD and atopic march via a TSLP dependent mechanism.

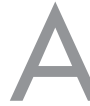

topic diseases, including atopic dermatitis (AD) and asthma, sharing similar genetic and environmental risk factors, have increased in prevalence in recent decades, and now affect approximately $20 \%$ of the population in the developed countries ${ }^{1,2}$. $\mathrm{AD}$ is a chronic pruritic inflammatory disease, and the pathogenesis of $\mathrm{AD}$ includes disrupted epidermal barrier function, immunodysregulation, and IgE-mediated sensitization to food and environmental allergens. Allergic asthma is characterized by a Th2 dominant airway inflammation and airway hyperresponsiveness (AHR) associated with airway remodeling. Recent multiple cross-sectional and longitudinal studies strongly support a temporal pattern of progression from atopic dermatitis to asthma, the so-called atopic march ${ }^{3-7}$. A causal link between $\mathrm{AD}$ and allergic asthma has been supported by clinical studies showing that in infants with $\mathrm{AD}, 43 \%$ developed asthma and $45 \%$ developed allergic rhinitis as young children ${ }^{7}$. $\mathrm{AD}$ has been considered a major risk factor for the development of asthma, with an increased odds ratio in children with $\mathrm{AD}$ in several longitudinal studies compared with children without $\mathrm{AD}^{8}$. Research on the mechanisms of AD has been centered on the Th1-Th2 paradigm. Recently, the conceptual focus on understanding $\mathrm{AD}$ has increasingly shifted to including a primary defect in the epithelial barrier as an initial event in the atopic march. Many studies in animal models demonstrate that epidermal barrier dysfunction can be caused by repeated sensitization to allergens to the skin, which leads to phenotypes of atopic dermatitis, systemic sensitization, increased risk of allergic rhinitis, lung inflammation and $\mathrm{AHR}^{9,10}$.

Thymic stromal lymphopoietin (TSLP), an epithelial-derived cytokine critical in Th2 immunity, has been shown to be highly increased in human $\mathrm{AD}$ skin as well as in the blood of patients with $\mathrm{AD}^{11,12}$. Recent studies in animal models suggest that keratinocyte-produced TSLP may be involved as a link between atopic dermatitis and asthma. A lack of the Notch signaling in the mouse skin results in skin-barrier defects and significant elevation of serum TSLP triggering bronchial hyperresponsiveness to inhaled allergens in the absence of epicutaneous allergen sensitization ${ }^{13}$. Induced expression of TSLP in mouse epidermal keratinocytes upon topical application of calcemic analogue of vitamin D3 triggers $\mathrm{AD}$ and aggravates experimental allergic asthma upon ovalbumin sensitization and challenge ${ }^{14}$. These studies suggest that elevated serum levels of TSLP may be responsible for the asthma phenotype in these models.

Interleukin 13 (IL-13), a critical cytokine in several human atopic disorders including asthma and allergic rhinitis, is remarkably increased in acute and chronic eczematous skin lesions of patients with $\mathrm{AD}^{15}{ }^{16}$. We previously showed that transgenic expression of IL-13 in the skin causes remarkable inflammatory cell infiltrates (CD4+, Langerhans cells, eosinophils and mast cells) and increased levels of IL-4 and IL-13 by CD4+ cells of draining lymph nodes, splenic cells, serum total IgE and IgG1 in the absence of epicutaneous allergen sensitization. We observed that TSLP was robustly upregulated in keratinocytes of mice with AD, and the level of TSLP was significantly increased in the $\mathrm{AD}$ skin of $\operatorname{Tg}(+)$ mice compared to $\operatorname{Tg}(-)$ mice $^{17}$. However, whether IL-13 
induced $\mathrm{AD}$ can promote allergic asthmatic responses in the lung and whether upregulated TSLP in the skin is involved in the process have not been investigated.

In this study, we tested the hypothesis that IL-13 induced atopic dermatitis predisposes to increased susceptibility to allergen stimulated inflammatory and asthmatic responses and TSLP signaling plays an important role in this progression from $\mathrm{AD}$ to asthma. We used the dermal transgenic IL-13-induced AD model in combination with suboptimal Ova challenge after sensitization and demonstrated that that only $\operatorname{Tg}(+)$ mice that developed AD had enhanced lung inflammation and AHR and IL-13-induced AD and increased allergic asthma responses to allergen is dependent on TSLP signaling.

\section{Results}

IL-13-induced AD is associated with enhanced lung inflammation upon suboptimal allergen challenge. We previously showed that selective expression of IL-13 in the skin induces an atopic dermatitis like phenotype characterized by intense pruritus, erythema, and erosions in the acute phase, and dry, lichenified skin in the chronic phase with skin remodeling and prominent dermal Th2-inflammatory infiltrates. The AD was associated with a systemic Th2 environment including increased levels of total serum IgE and production of IL- 4 and IL-13 by CD4+ cells from draining lymph nodes (DLN) and splenic cells ${ }^{17}$.

In the present study, we investigated whether IL-13-induced AD and the associated systemic Th2 environment would render increased susceptibility to allergic asthma. To test this, we used a modified suboptimal Ova-induced asthma protocol, in which 2, instead of 3, consecutive airway inhalations of allergen were used for challenge after sensitization. $\operatorname{Tg}(-)$ mice and $\operatorname{Tg}(+)$ mice that developed AD (with a clinical score $\leq 2 ;{ }^{17}$ ) were sensitized (days 0 and 7) via intraperitoneal (i.p.) injections of Ova and Alum and challenged with two doses of inhaled Ova on days 21 and 22. The control mice were injected i.p. with Alum alone and challenged with vehicle PBS (Figure 1a).

There were rare inflammatory cells noted in PBS-challenged $\operatorname{Tg}(-)$ and PBS-challenged $\operatorname{Tg}(+)$ lungs (Figure 1b). Remarkable inflammatory cells were accumulated in peribronchial and perivascular areas in the lungs of Ova-challenged $\mathrm{Tg}(+)$ mice compared to Ova-challenged $\operatorname{Tg}(-)$ mice. Alcian blue staining of the lung sections showed strong positive acidic mucus producing goblet cells (sky blue) in the airways of Ova-challenged $\mathrm{Tg}(+)$ mice compared to those in the airways of Ova-challenged $\operatorname{Tg}(-)$ mice (Figure 1c). In addition, the total inflammatory cells collected from bronchial lavage fluids (BAL) (Figure 1d) and the numbers of eosinophils, lymphocytes and macrophages were significantly higher in Ova-challenged $\operatorname{Tg}(+)$ mice than those in Ova-challenged $\operatorname{Tg}(-)$ mice (Figure 1e). The numbers of total and differential cells in BAL fluids were comparable among Ova-challenged $\operatorname{Tg}(-)$ mice and PBS-challenged $\operatorname{Tg}(+)$ and $\operatorname{Tg}(-)$ mice. These data showed that $\operatorname{Tg}(+)$ mice that had $\mathrm{AD}$ developed enhanced lung inflammation to suboptimal allergen challenge, in contrast to Ova-challenged $\operatorname{Tg}(-)$ mice that did not mount significant lung inflammation. Accordingly, the levels of IL- 4 and IL-13 were increased in the BAL fluids of Ova-challenged $\operatorname{Tg}(+)$ mice compared to those of Ova-challenged $\operatorname{Tg}(-)$ mice (Figure 1f, 1g), but the levels of IFN- $\gamma$ were comparable among all groups (Figure 1h).

IL-13-induced AD is associated with enhanced airway resistance upon suboptimal allergen challenge. AHR is one of the cardinal features in human asthma and in experimental asthma. We used both invasive and noninvasive pulmonary function test (PFT) techniques to determine alterations in airway physiology of the mice in response to increasing doses of methacholine after allergen challenge (protocol in Figure 1a). Ova-challenged $\mathrm{Tg}(+)$ mice with
AD began to exhibit significantly enhanced airway resistance (R) $\left(\mathrm{cmH}_{2} \mathrm{O} \cdot \mathrm{S} / \mathrm{ml}\right)$ at $12.5 \mathrm{mg} / \mathrm{ml}$ and $25 \mathrm{mg} / \mathrm{ml}$ of methacholine (Figure 2a) and significantly reduced lung compliance (C) $\left(\mathrm{ml} / \mathrm{cmH}_{2} \mathrm{O}\right)$ at $50 \mathrm{mg} / \mathrm{ml}$ of methacholine compared to those of $\operatorname{Tg}(-)$ mice challenged with Ova (Figure 2b), which was comparable to PBS-control groups. Consistent with enhanced AHR in the Ova-challenged $\operatorname{Tg}(+)$ mice measured by invasive PFT, using a non-invasive PFT technique, an exaggerated AHR (Penh) in the Ova-challenged $\operatorname{Tg}(+)$ mice was also demonstrated in response to methacholine (Figure $2 \mathrm{c}$ ).

Taken together, these studies demonstrated that suboptimal Ova challenge to the airway was insufficient to cause lung inflammation and AHR in $\operatorname{Tg}(-)$ mice, but sufficient to provoke significant lung inflammation and AHR in $\mathrm{Tg}(+)$ mice that developed $\mathrm{AD}$, indicating that these mice had increased susceptibility to allergen induced allergic asthma responses.

Atopic dermatitis is important for the development of AHR. We next investigated whether $\operatorname{Tg}(+)$ mice without clinical $\mathrm{AD}$, when sensitized and challenged by Ova allergen, could also develop enhanced AHR upon methacholine challenge. $\operatorname{Tg}(+)$ mice that presented with clinical AD (clinical score $>2$ ) and $\operatorname{Tg}(+)$ mice that did not show clinical AD (the IL-13 transgene was on for $<8$ weeks) were sensitized and challenged per the protocol (Figure 1a). Histologically, the skin samples of $\operatorname{Tg}(+)$ mice without $\mathrm{AD}$ did not display significant skin inflammatory response. Conversely, the skin samples of $\operatorname{Tg}(+)$ mice with $\mathrm{AD}$ showed extensive inflammatory infiltrates (Figure 3a, 3b). Airway hyperresponsiveness (Penh) was compared between $\operatorname{Tg}(+)$ mice that did not develop clinical $\mathrm{AD}$ and $\mathrm{Tg}(+)$ mice that did in response to increased doses of methacholine. Only $\operatorname{Tg}(+)$ mice with AD showed exaggerated AHR at 25 and $50 \mathrm{mg} / \mathrm{ml}$ of methacholine (Figure 3c), strongly indicating that $\mathrm{AD}$ is important for the development of allergic asthma in this model. Increased levels of IL-13 could be found in the serum of $\operatorname{Tg}(+)$ mice as compared to $\operatorname{Tg}(-)$ mice. However, there was no significant difference in the serum levels of IL-13 between $\operatorname{Tg}(+)$ mice with mild AD that developed AHR and those $\operatorname{Tg}(+)$ mice without AD that did not exhibit AHR, suggesting that serum IL-13 in these mice was not a determinant in inducing atopic march (Figure 3d).

Differential expression of TSLP in IL-13-induced acute and chronic lesions. We previous showed that TSLP was highly expressed by keratinocytes in IL-13-induced AD skin ${ }^{17}$. We further characterized the expression of TSLP in the skin at different stages of $\mathrm{AD}$ and found that TSLP expressed by keratinocytes of $\operatorname{Tg}(+)$ mice was robustly higher in the acute $\mathrm{AD}$ lesions (Clinical score $\leq 2$ and induction of the IL-13 transgene $<10$ weeks) than that in the chronic $\mathrm{AD}$ (Figure 4a). However, the serum levels of TSLP in $\operatorname{Tg}(+)$ mice that developed $\mathrm{AD}$ were barely detectable, similar to the serum levels of TSLP in $\operatorname{Tg}(+)$ mice without AD and to those in $\operatorname{Tg}(-)$ mice (Figure 4b). These results suggest that the early exaggerated production of TSLP in acute AD skin lesions might be important for initiating the atopic march but may be not through serum TSLP.

TSLPR deficiency attenuates IL-13-induced AD. The role of TSLP signaling in promoting Th2 inflammation in asthma and AD has been recognized ${ }^{11,18-20}$. And its role in the atopic march has been proposed $^{13},{ }^{14}$. However, whether TSLP plays any role in IL-13induce atopic march is not known. We investigated the importance of the TSLP-TSLPR signaling pathway in AD and in subsequent atopic march induced by IL-13. K5-tTA-IL-13 mice carrying the wild type TSLP receptor gene $\operatorname{Tg}(+) / \operatorname{TSLPR}(+/+)$ and the null mutation of the TSLP receptor gene $\mathrm{Tg}(+) /$ $\operatorname{TSLPR}(-/-)$ on a C57BL/6 genetic background were first compared for clinical $\mathrm{AD}$ and skin inflammation. Lack of TSLP receptor in $\mathrm{IL}-13 \mathrm{Tg}(+)$ mice $(\operatorname{Tg}(+) / \operatorname{TSLPR}(-/-))$ resulted in 


\section{(a) Experimental protocol}

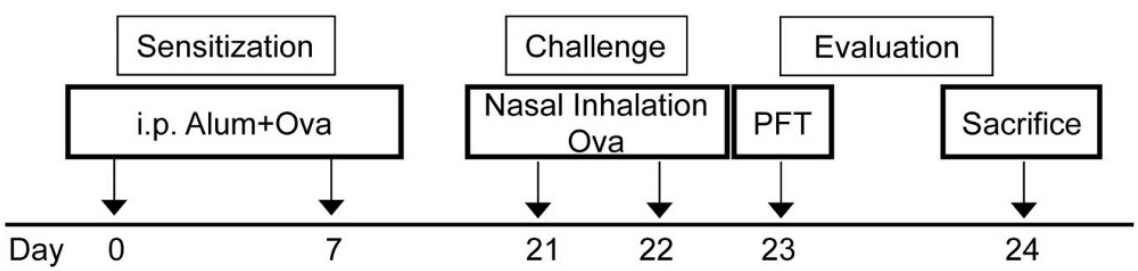

(b)

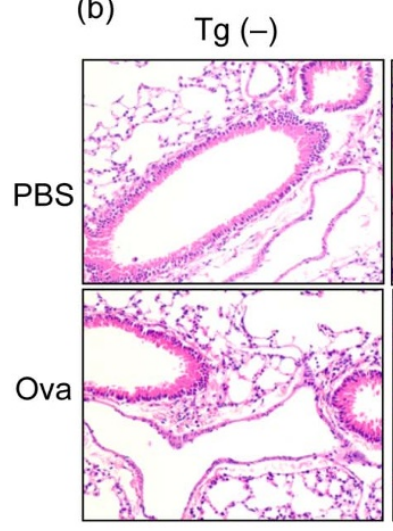

$\operatorname{Tg}(+)$

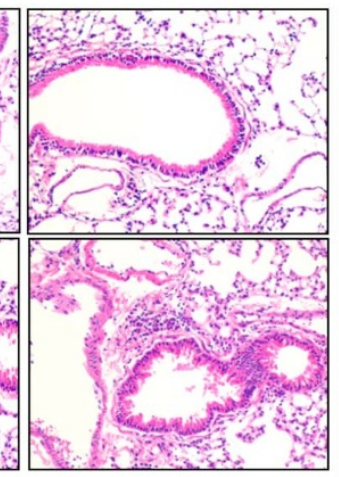

(c)

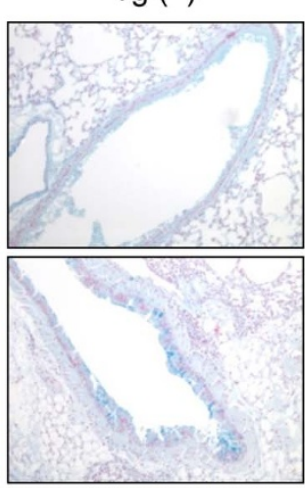

$\operatorname{Tg}(+)$

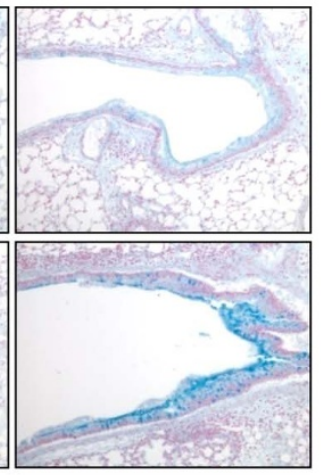



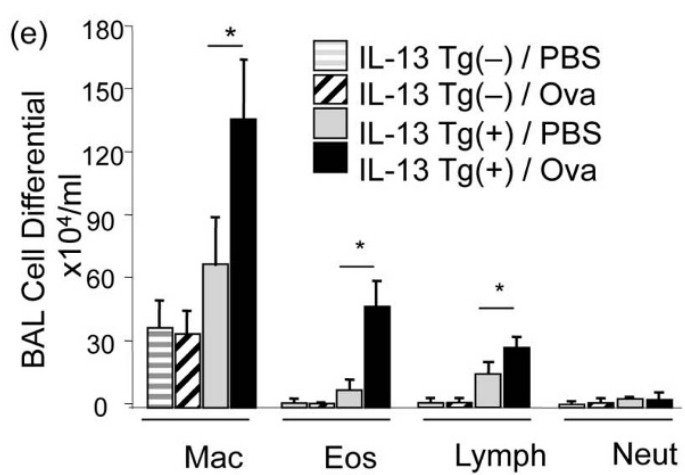

(h)
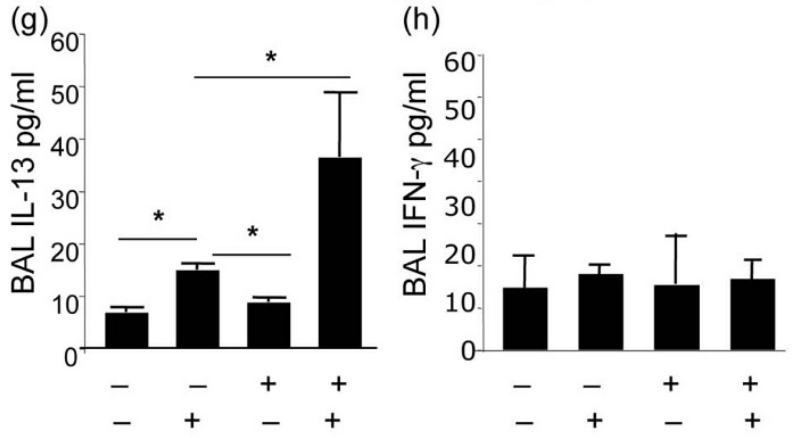

Figure $1 \mid$ IL-13 Tg mice with AD sensitized and challenged with Ova had significantly increased lung inflammation. (a) A modified experimental protocol was used to detect exaggerated response in $\mathrm{Tg}(+)$ mice with AD to inhaled Ova challenge. K5-tTA-IL-13 (Tg) $(+)$ mice that developed AD $(\mathrm{AD}$ score $>2$ ) and their $\operatorname{Tg}(-)$ littermates were tested and compared. (b) Lung histology (H\&E) showing increased infiltrating cells in the peribronchial and perivascular areas of the lung from Ova-challenged $\operatorname{Tg}(+)$ mice, predominant eosinophils and mononuclear cells as compared to $\mathrm{Tg}(-) \mathrm{mice}$. (c) $\mathrm{Alcian}$ blue staining of lung sections showing mucus producing goblet cells (sky blue). Mucus metaplasia was more prominent in the airways of Ova-challenged $\operatorname{Tg}(+)$ mice than that in the airways of Ova-challenged $\operatorname{Tg}(-)$ mice. (d) BAL total cell counts. Significant increases in the number of total inflammatory cells collected from BAL fluids in Ova-challenged $\mathrm{Tg}(+)$ mice and (e) BAL cell differential. Significantly increased eosinophils, lymphocytes and macrophages compared to Ova-challenged $\mathrm{Tg}(-)$ mice. (f) IL-4 levels, (g) IL-13 levels, and (h) IFN- $\gamma$ levels in the BAL samples from $\mathrm{Tg}(+)$ and $\mathrm{Tg}(-)$ mice. ( ${ }^{*} P<0.05 ;{ }^{*} P<0.01 ; \mathrm{n}=10$ mice for each group).

remarkably less itchy/scratch behavior, a cardinal feature of human $\mathrm{AD}$, than that of $\operatorname{Tg}(+)$ mice carrying wild type TSLPR $(\operatorname{Tg}(+) /$ $\operatorname{TSLPR}(+/+)$ ) (Figure 5a). In addition, $\operatorname{Tg}(+) / \operatorname{TSLPR}(-/-)$ mice showed milder $\mathrm{AD}$ in the early course of $\mathrm{AD}$ development $(10$ and 12 weeks after transgene induction) than $\operatorname{Tg}(+) / \operatorname{TSLPR}(+/+)$ mice. But at the late stage ( $>14$ weeks) this difference was not significant
(Figure 5b). Thus TSLP signaling is more important in the early pathogenesis of IL-13-induced AD.

Histological examination of skin inflammation using H\&E revealed that $\operatorname{Tg}(+)$ mice lacking TSLPR $(\operatorname{Tg}(+) / \operatorname{TSLPR}(-/-))$ exhibited milder inflammatory infiltrates (Figure 5c) and lower numbers of inflammatory cells compared to the $\mathrm{AD}$ skin samples 




$\operatorname{Mch}(\mathrm{mg} / \mathrm{ml}) \quad 0 \quad 3.12 \quad 6.2512 .5 \quad 25 \quad 50$

(b)

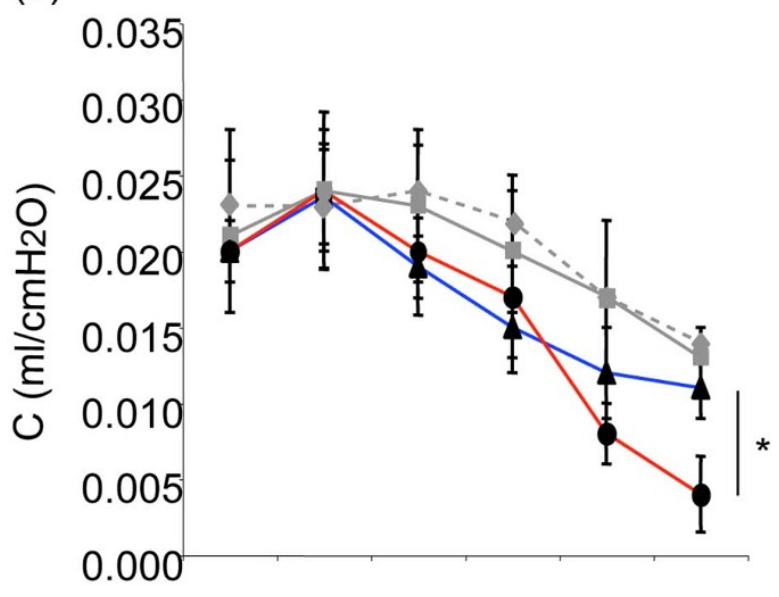

Mch (mg/ml) $0 \begin{array}{lllll}0.12 & 6.25 & 12.5 & 25 & 50\end{array}$

(c)

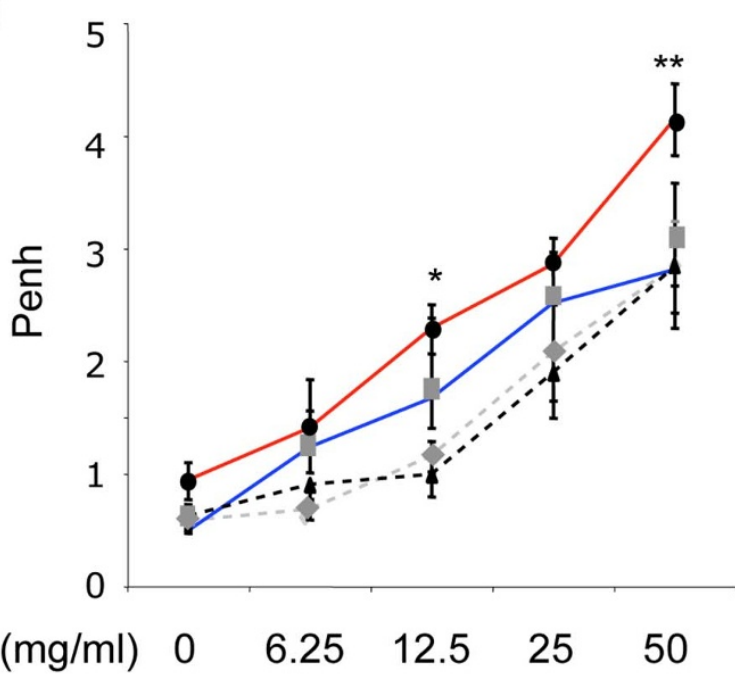

from $\operatorname{Tg}(+) / \operatorname{TSLPR}(+/+)$ mice (Figure 5d). In IHC, using monoclonal antibodies against CD4 and F4/80 (BM8) for detecting CD4+ cells and activated Langerhans cells/macrophages, respectively, significantly lower numbers of CD4+ cells and Langerhans cells were found in the AD skin samples from $\operatorname{Tg}(+) / \operatorname{TSLPR}(-/-)$ mice compared to $\operatorname{Tg}(+) / \operatorname{TSLPR}(+/+)$ mice (Figure 5e, 5f). Using Toluidine Blue staining for detecting mast cells and H\&E staining for detecting eosinophils, the numbers of mast cells and eosinophils were also significantly reduced in the AD skin samples of $\mathrm{Tg}(+) /$ TSLPR $(-/-)$ mice compared to those in the AD skin of $\operatorname{Tg}(+) /$ $\operatorname{TSLPR}(+/+)$ mice (Figure $5 \mathrm{~g}$ and Table $\mathbf{1})$. These studies demonstrated that TSLP signaling is vital for the severity of IL-13-induced $\mathrm{AD}$ by regulating inflammatory cells critical for the pathogenesis of AD. Deficiency of TSLPR in IL-13 mice did not alter the level of dermal IL-13, however, indicating that alteration of dermal inflammation by eliminating TSLPR in $\operatorname{Tg}(+)$ mice was not due to inhibition of the IL-13 transgene expression (Supplemental Fig. S1). The levels of TSLP in the skin and in the serum of $\operatorname{Tg}(+) / \operatorname{TSLPR}(+/+)$ and $\operatorname{Tg}(+) / \operatorname{TSLPR}(-/-)$ mice were not significantly altered either (Supplemental Fig. S1).

TSLPR deficiency attenuates IL-13-induced atopic march. We next investigated the role of TSLP signaling in IL-13 triggered atopic march. $\operatorname{Tg}(+) / \operatorname{TSLPR}(+/+)$ and $\operatorname{Tg}(+) / \operatorname{TSLPR}(-/-)$ mice that exhibited clinical $\mathrm{AD}$ (clinical score $>2$ ) and $\mathrm{Tg}(-) / \mathrm{TSLPR}$ $(+/+)$ and $\operatorname{Tg}(-) / \operatorname{TSLPR}(-/-)$ mice on C57BL/6 background as controls were analyzed. After the mice were sensitized and challenged with Ova or PBS per protocol in Figure 1a, lung inflammation in peribronchial regions was significantly enhanced in the $\operatorname{Tg}(+) / \operatorname{TSLPR}(+/+)$ mice. Conversely, inflammatory cells in the airway of $\operatorname{Tg}(+) / \operatorname{TSLPR}(-/-)$ mice were attenuated (Figure 6a, 6b). Correspondingly, the number of total inflammatory cells collected from BAL fluids and the numbers of eosinophils, lymphocytes and macrophages were markedly decreased in $\operatorname{Tg}(+)$ mice deficient in TSLPR $(\operatorname{Tg}(+) / \operatorname{TSLPR}(-/-))$ compared to those of $\operatorname{Tg}(+)$ mice with wild-type $\operatorname{TSLPR}(\operatorname{Tg}(+) / \operatorname{TSLPR}(+/+))$ (Figure 6c, 6d). The levels of TSLP in the lung tissue and BALs of $\operatorname{Tg}(+) / \operatorname{TSLPR}(+/+)$ and $\operatorname{Tg}(+) / \operatorname{TSLPR}(-/-)$ mice were not significantly altered in the absence of the sensitization and challenge of allergen (Ova) (Supplemental Fig. S1).

Using invasive PFT, airway resistance (R) and lung compliance (C) in response to increased doses of methacholine were assessed. $\operatorname{Tg}(+)$ mice carrying the wild type TSLPR manifested a heightened AHR. In contrast, deletion of TSLPR in $\mathrm{Tg}(+)$ mice significantly attenuated airway resistance (R) at $50 \mathrm{mg} / \mathrm{ml}$ and $100 \mathrm{mg} / \mathrm{ml} \mathrm{of}$ methacholine (Figure 7a). In accord with these findings, lung compliance $(\mathrm{C})$ was significantly improved in $\operatorname{Tg}(+)$ mice carrying null mutation of TSLPR $(\operatorname{Tg}(+) / \operatorname{TSLPR}(-/-))$ compared to $\operatorname{Tg}(+)$ mice carrying wild type TSLPR $(\operatorname{Tg}(+) / \operatorname{TSLPR}(+/+))$ (Figure $7 \mathbf{b})$.

Figure $2 \mid \mathrm{IL}-13 \mathrm{Tg}(+)$ mice with $\mathrm{AD}$ sensitized and challenged with Ova had significantly worse lung functions. Using invasive pulmonary function test $(\mathrm{PFT})$, total airway resistance $\left(\mathrm{R}\left(\mathrm{cmH}_{2} \mathrm{O} \bullet \mathrm{s} / \mathrm{ml}\right)\right)$ and lung compliance $\left(\mathrm{C}\left(\mathrm{ml} / \mathrm{cmH}_{2} \mathrm{O}\right)\right)$ at baseline (vehicle alone; 0$)$ and in response to increasing doses of methacholine $(3.12,6.25,12,25$, and $50 \mathrm{mg} / \mathrm{ml})$ were assessed in Ova-challenged $\mathrm{Tg}(+)$ and $\mathrm{Tg}(-)$ mice and PBS-control $\operatorname{Tg}(+)$ and $\operatorname{Tg}(-)$ mice one day after the last inhaled Ova challenge. (a) In invasive PFT, Ova challenged $\operatorname{Tg}(+)$ mice that developed $\mathrm{AD}$ mounted exaggerated airway resistance at 12.5 and $25 \mathrm{mg} / \mathrm{ml}$ of methacholine and (b) exhibited reduced lung compliance at $50 \mathrm{mg} / \mathrm{ml}$ of methacholine after a suboptimal Ova challenge, whereas, Ova-challenged $\operatorname{Tg}(-)$ mice did not exhibit increased $\mathrm{R}$ and reduced $\mathrm{C}$ compared to PBS-control groups. (c) Increased AHR (Penh) was also demonstrated in Ova treated $\operatorname{Tg}(+)$ mice by noninvasive PFT. These measurements are confirmed in 2 more sets of experiments. $\left({ }^{*} \mathrm{P}<0.05,{ }^{* *} \mathrm{P}<0.01 . \mathrm{n}=10\right.$ for each Ova group and $\mathrm{n}=5$ for each control group). 
(a)
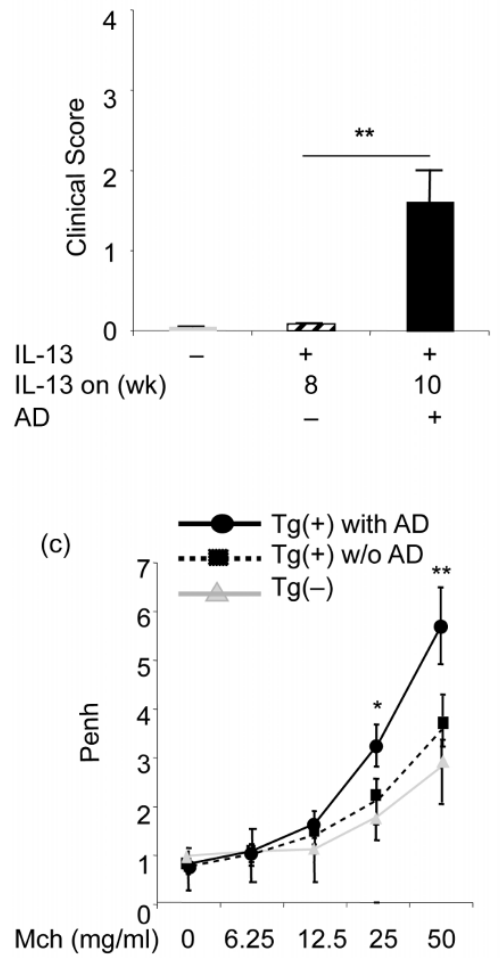

(b)
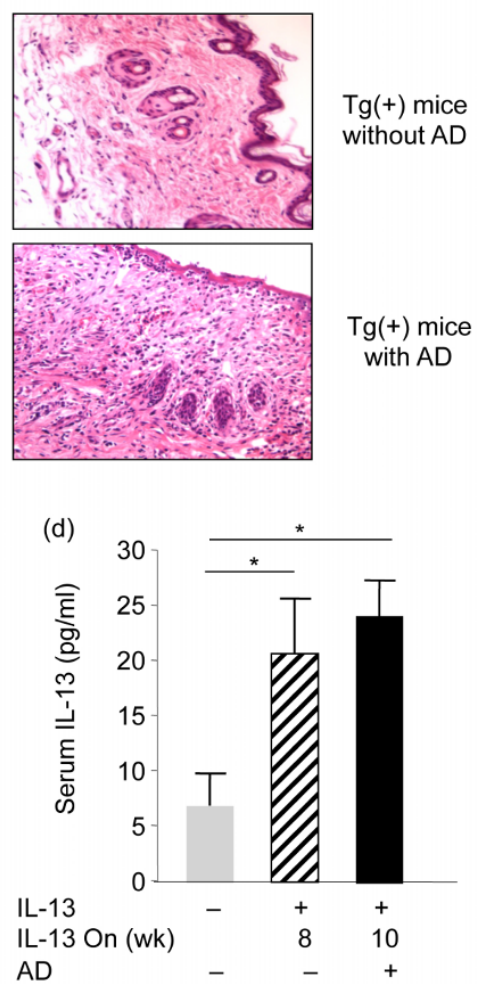

Figure 3 Relationship between onset of atopic dermatitis and the development of exaggerated AHR. Induction of IL-13 transgenic expression was initiated for different time periods and the development of clinical and histological $\mathrm{AD}$ and its correlation with changes in lung physiology were assessed. (a) Clinical AD scores of $\mathrm{Tg}(+)$ mice at different time after IL-13 induction, with $\mathrm{Tg}(-)$ mice as controls. (b) Histological examination (H\&E) showed greatly increased inflammatory infiltrate in the skin of $\operatorname{Tg}(+)$ mice with $\mathrm{AD}$ compared to minimal inflammatory infiltrates in $\mathrm{Tg}(+)$ mice without $\mathrm{AD}$. (c) $\mathrm{Tg}(+)$ mice with AD showed enhanced AHR (Penh) compared to $\mathrm{Tg}(+)$ mice that did not have $\mathrm{AD}$ and to $\mathrm{Tg}(-)$ mice. $(\mathrm{d}) \mathrm{Serum} \mathrm{IL}-13$ levels in $\operatorname{Tg}(-)$ mice and $\operatorname{Tg}(+)$ mice with or without $\mathrm{AD}$. $\left({ }^{*} \mathrm{P}<0.05, * * \mathrm{P}<0.01 ; \mathrm{n}=8-10\right.$ each $\operatorname{Tg}(+)$ group and $\mathrm{n}=6$ for each $\mathrm{Tg}(-)$ control group $)$.
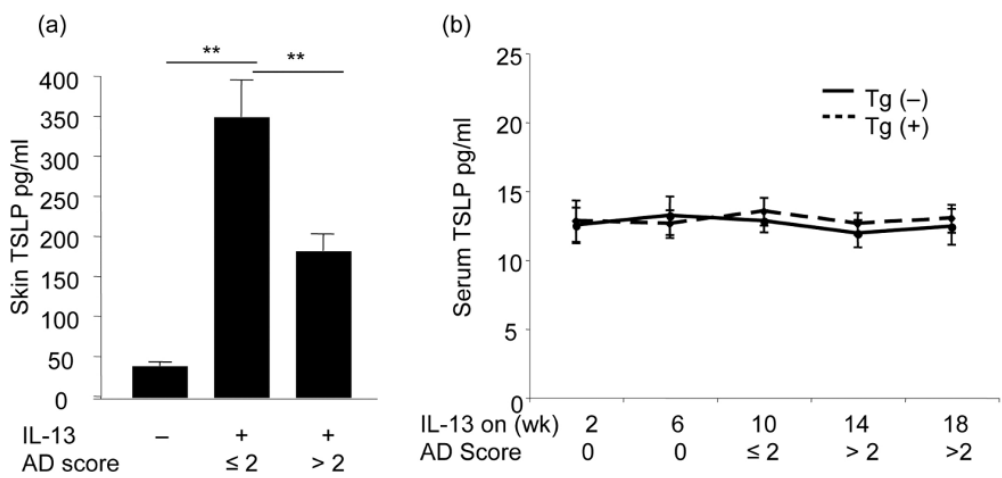

Figure $4 \mid$ Association of IL-13-induced AD with alterations of the TSLP levels in the skin and in the serum. The levels of TSLP protein in the skin and serum were assessed by ELISA. (a) Significantly higher levels of TSLP in the skin of $\operatorname{Tg}(+)$ mice than in $\operatorname{Tg}(-)$ mice and the difference was more prominent in acute AD than in chronic AD. (b) Serum levels of TSLP in $\operatorname{Tg}(+)$ mice after induction of IL-13 transgene and compared with $\mathrm{Tg}(-)$ mice receiving the same treatment. $\left({ }^{*} \mathrm{P}<0.01 ; \mathrm{n}=8\right.$ for $\operatorname{Tg}(-)$ group and $\mathrm{n}=10$ for each $\operatorname{Tg}(+)$ group).

Measurement of cytokines in the BAL samples showed that IL-13 $\operatorname{Tg}(+)$ mice with wild type TSLPR had significantly increased production of IL- 4 and IL-13 in the airways after suboptimal Ova challenge compared to $\operatorname{Tg}(-)$ mice with or without TSLPR. In contrast, $\operatorname{Tg}(+)$ mice with null mutant TSLPR had reduced levels of BAL IL-4 and IL-13 after Ova challenge (Figure 7c, 7d). The levels of Th1 cytokine, IFN- $\gamma$ in the airways were not altered among all groups (Figure 7e).

TSLPR deficiency diminished the systemic Th2 immune environment in IL-13 $\operatorname{Tg}(+)$ mice. To better understand the role of TSLP signaling in IL-13 triggered AD and increased susceptibility to allergic asthma, we determined the changes in the systemic Th2 dominated immune environment by measuring the serum levels of $\operatorname{IgE}$ and the production of Th2 and Th1 cytokines by immune cells in mice with or without the null mutation in TSLPR. CD4+ cells and lymphocytes purified from spleen and draining lymph nodes (inguinal, subclavical and axillary regions) were activated by anti-CD3/CD28 for 3 days and Th2 cytokines (IL-4 and IL-13) and Th1 cytokine IFN- $\gamma$ were measured and compared between $\operatorname{Tg}(+)$ mice carrying wild type TSLPR and $\operatorname{Tg}(+)$ mice carrying null-mutated TSLPR. 
(a)

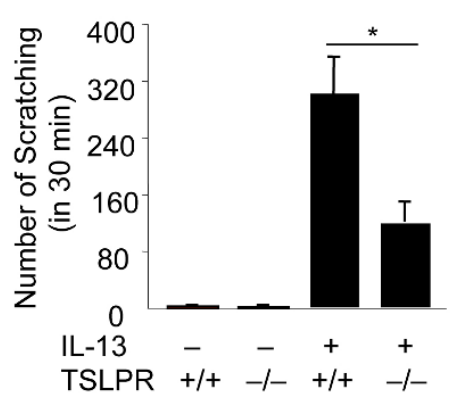

(b)

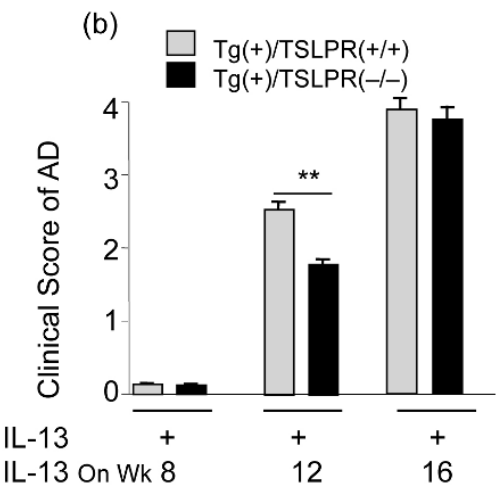

(c)

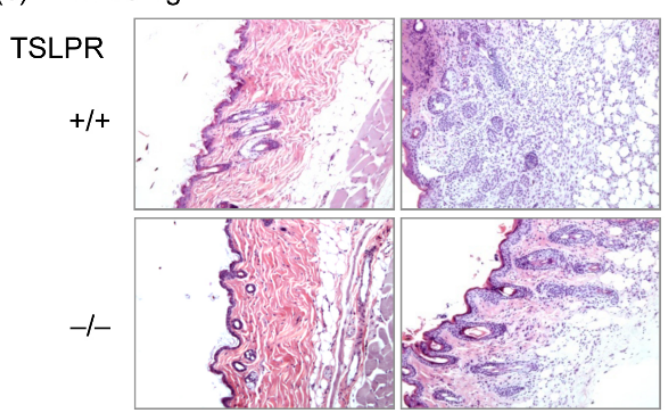

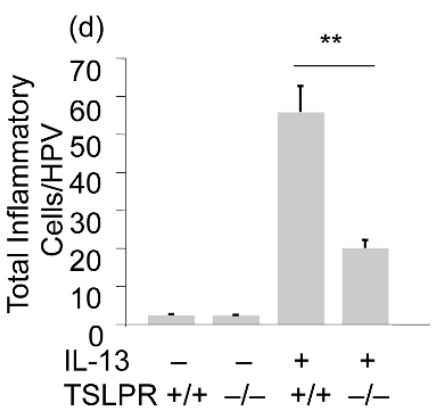

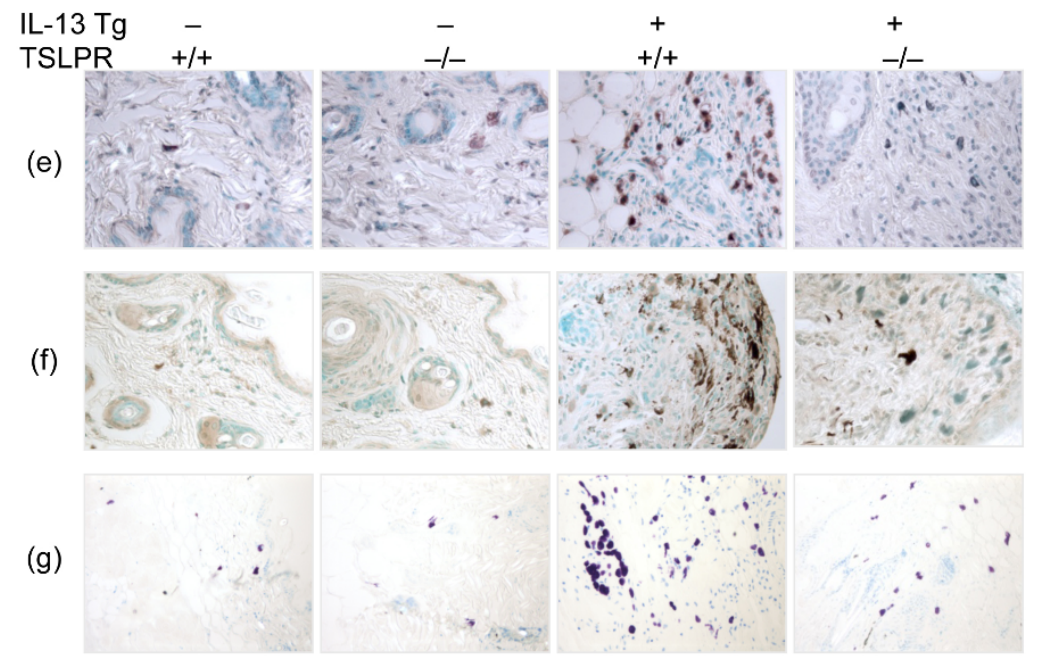

Figure $5 \mid$ Deletion of TSLPR in $\mathrm{Tg}(+)$ mice attenuated IL-13-induced AD. (a) Itch/scratch behavior was video recorded and counted. Shown are the numbers of scratches per $30 \min (\operatorname{Tg}(-)$ mice $n=6 ; \operatorname{Tg}(+)$ mice $n=8)$. (b) Clinical AD scores in the early stages of AD development were significantly reduced in $\operatorname{Tg}(+) / \operatorname{TSLPR}(-/-)$ mice compared to those in $\operatorname{Tg}(+) / \operatorname{TSLPR}(+/+)$ mice $(\mathrm{Tg}(+) / \mathrm{TSLPR}(+/+)$ mice $\mathrm{n}=4$ and $\mathrm{Tg}(+) / \mathrm{TSLPR}(-/-)$ mice $\mathrm{n}=8$ ). (c) Histological evaluation of skin sections (H\&E, 10×) and (d) Quantitative evaluation of the inflammatory cells (high power field). (e) IHC evaluation of CD4+ cells with monoclonal anti-CD4 antibody and (f) Langerhans cells/Macrophages with monoclonal anti-F4/80 antibody.

(g) Toluidine blue staining for mast cells in the skin. Quantification of these cells, including eosinophil evaluation by H\&E, is shown in Table 1. For all comparisons, $* \mathrm{P}<0.05, * * \mathrm{P}<0.01$.

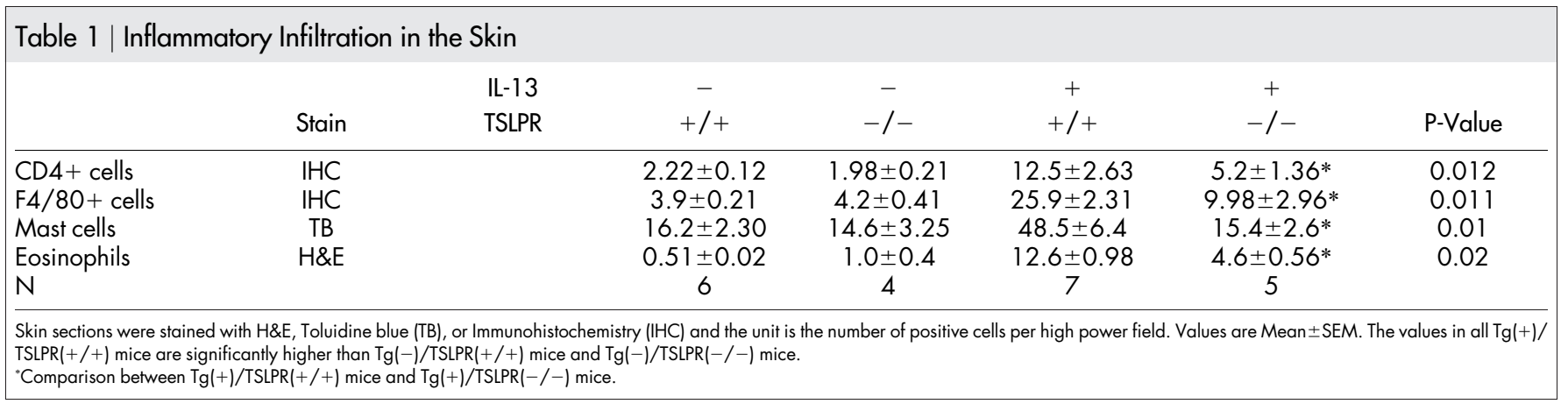



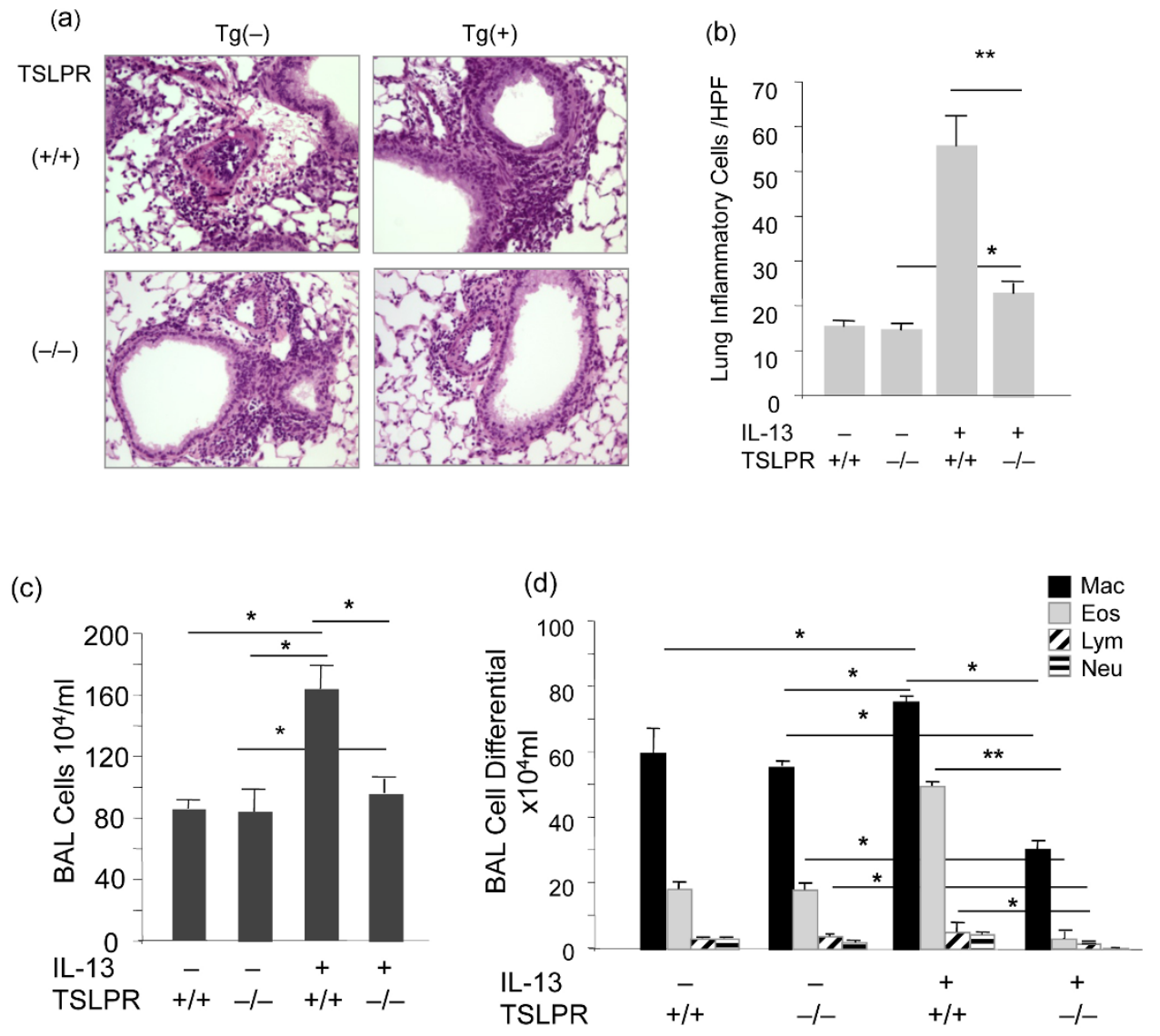

Figure 6 Deletion of TSLPR in $\operatorname{Tg}(+)$ mice attenuated IL-13-induced enhanced lung inflammation upon Ova challenge. After Ova sensitization and challenge, inflammatory responses in the lung of $\operatorname{Tg}(-) / \operatorname{TSLPR}(+/+), \operatorname{Tg}(-) / \operatorname{TSLPR}(-/-), \operatorname{Tg}(+) / \operatorname{TSLPR}(+/+)$ and $\mathrm{Tg}(+) / \operatorname{TSLPR}(-/-)$ mice were assessed. (a) H\&E evaluation (10×) of lung tissue inflammation; (b) Quantification of inflammatory cells in lung tissue; (c) Total inflammatory cells in BAL and $(\mathrm{d})$ Cell differentials in the BAL fluids showing greatly reduced inflammatory responses in the $\operatorname{Tg}(+) / \mathrm{TSLPR}(-/-)$ mice compared to the $\operatorname{Tg}(+) / \operatorname{TSLPR}(+/+)$ mice. $\left(\mathrm{n}=8\right.$ mice for each $\mathrm{Tg}(-)$ groups and $\mathrm{n}=10$ for each $\mathrm{Tg}(+)$ group, $\left.{ }^{*} \mathrm{P}<0.05,{ }^{*} \mathrm{P}<0.01\right)$.

$\operatorname{Tg}(-)$ mice with or without TSLPR mutant had low levels of serum total $\operatorname{IgE}$ and Ova-specific $\operatorname{IgG} 1$, whereas $\operatorname{Tg}(+)$ mice with wild type TSLPR showed significantly increased levels of serum total $\mathrm{IgE}$ and Ova-specific IgG1. Elimination of TSLPR in the $\mathrm{Tg}(+)$ mice, however, resulted in reduced levels of serum total IgE and Ovaspecific IgG1 (Figure 8a, 8b). However, no difference was noticed among all groups in the levels of Ova-specific IgG2a (Figure 8c).

Without any stimulation (medium control), lymphocytes and $\mathrm{CD} 4+\mathrm{T}$ cells from all the groups did not produce detectable cytokines (Figure 8d-i). Lymphocytes and CD4 $+\mathrm{T}$ cells isolated from $\operatorname{Tg}(-) / \operatorname{TSLPR}(+/+)$ mice and $\operatorname{Tg}(-) / \operatorname{TSLPR}(-/-)$ mice produced significant but comparable levels of IL-4 and IL-13. But cells from $\operatorname{Tg}(+) / \operatorname{TSLPR}(+/+)$ mice produced significantly higher levels of IL-4 and IL-13 compared to cells from $\operatorname{Tg}(-)$ mice (Figure 8d-g). However, the levels of IL-4 and IL-13 produced by lymphocytes and $\mathrm{CD}^{+} \mathrm{T}$ cells from $\mathrm{Tg}(+)$ mice with null mutant TSLPR were significantly lower than those by cells from $\operatorname{Tg}(+) / \operatorname{TSLPR}(+/+)$ mice (Figure 8d-g). On the other hand, the levels of IFN- $\gamma$ were not significantly altered among the $\operatorname{Tg}(+)$ groups (Figure $\mathbf{8 h}, \mathbf{8 i}$ ). When viewed together, these data suggest that the TSLP signaling pathway is critically involved in the IL-13 induced AD and increased susceptibility to Ova induced allergic asthma by promoting IL-4 and IL-13 production in spleen and lymph nodes leading to a systemic Th2 conducive environment for further development of allergic inflammatory responses to allergens.

\section{Discussion}

Multiple lines of evidence (clinical, genetic and experimental studies) suggest that prior expression of atopic dermatitis is a prerequisite for the development of allergic rhinitis and asthma, the process termed the atopic march. The temporal pattern described in the atopic march is strongly influenced by both genetic and environmental factors. The main risk factors for progression and persistence of human asthma are early onset, IgE sensitization, and severity of $\mathrm{AD}$. Approximately $60-70 \%$ of children with severe $\mathrm{AD}$ develop asthma comparing to $20-30 \%$ of children with mild AD and only $8 \%$ in the general population? ${ }^{7}$ The progression from AD to asthma is supported by studies using mouse models demonstrating that epicutaneous sensitization with ovalbumin induces localized $\mathrm{AD}$ and $\mathrm{AHR}$ to methacholine after challenge with aerosolized ovalbumin ${ }^{9}$ and that epicutaneous aeroallergen exposure induces systemic $\mathrm{Th} 2$ immunity that predisposes to allergic nasal responses, suggesting that the skin is a potent site for antigen sensitization in the development of experimental allergic rhinitis $^{21}$. Other murine models have shown that epicutaneous exposure to ovalbumin and peanut after the removal of the stratum corneum induces a strong systemic Th2 immune responses characterized by elevated IL- 4 secretion by $\mathrm{T}$ cells from draining lymph nodes and by high levels of allergen specific IgE and $\operatorname{IgG1} 1^{9,22}$. Two recent studies using different models of $\mathrm{AD}$ suggested that TSLP may be an important link between $\mathrm{AD}$ and increased susceptibility to allergen stimulation in the airway ${ }^{13,14}$. We previously reported that IL-13, when expressed in the skin, induced an AD-like disorder with significant upregulation of TSLP in keratinocytes ${ }^{17}$. In this study we investigated whether IL-13-induced $\mathrm{AD}$ is associated with increased susceptibility to allergen induced allergic responses in the lung and whether TSLP plays any role in this process.

Here we show that transgenic expression of IL-13 in the mouse skin not only induced $\mathrm{AD}$ but also led to significantly enhanced 
(a)

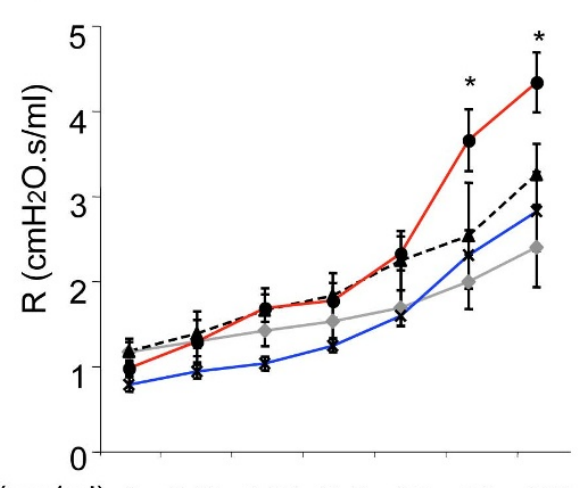

(b)

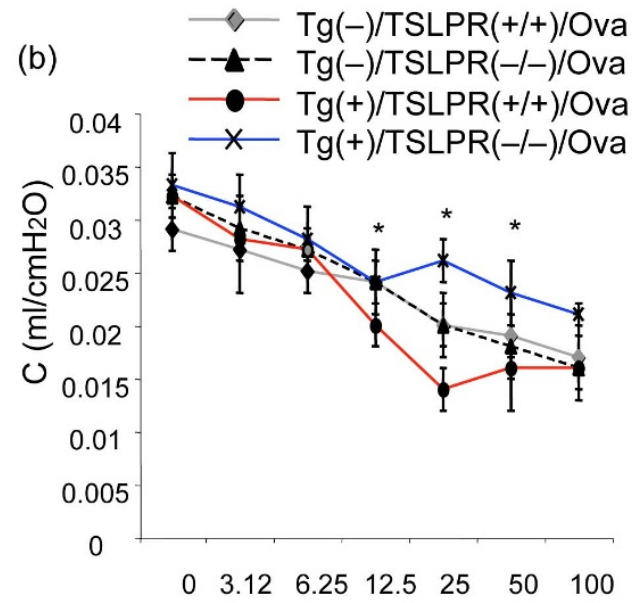

(c)

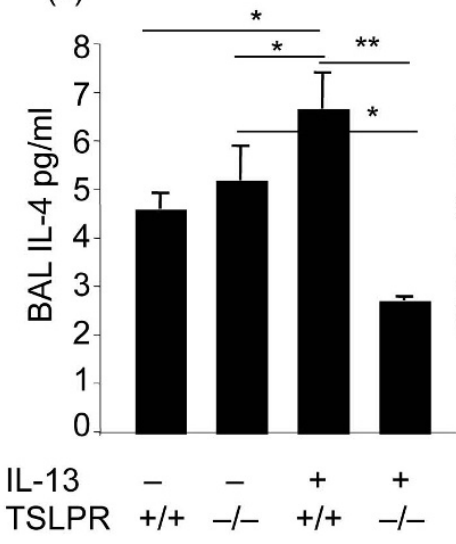

(d)

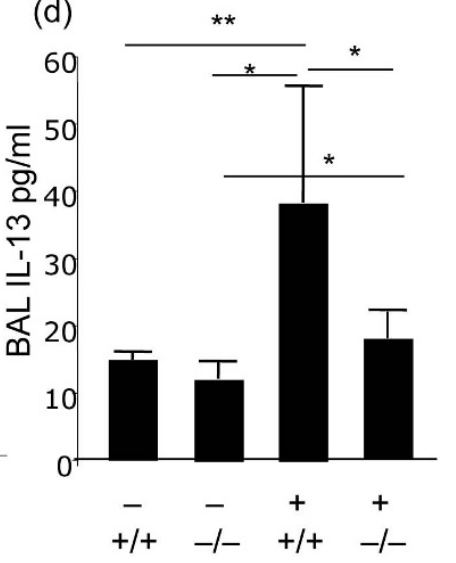

(e)

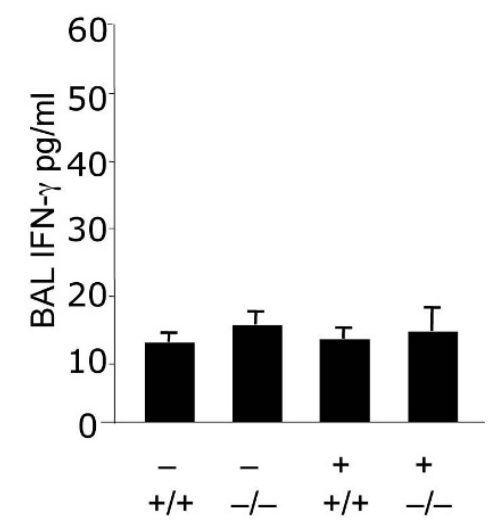

Figure $7 \mid$ Deletion of TSLPR diminished IL-13-induced and AD related alterations in pulmonary physiology. Using invasive PFT, comparing to $\mathrm{Tg}(+) / \operatorname{TSLPR}(+/+)$ mice, the $\mathrm{Tg}(+) / \operatorname{TSLPR}(-/-)$ mice exhibited (a) reduced airway resistance $R\left(\mathrm{cmH}_{2} \mathrm{O} \bullet \mathrm{s} / \mathrm{ml}\right)$ and (b) improved lung compliance $\mathrm{C}$ $\left(\mathrm{ml} / \mathrm{cmH}_{2} \mathrm{O}\right.$ ). ( $\mathrm{c}$ and d) These were associated with reduced levels of IL-4 and IL-13 in the BAL fluid by ELISA. (e) The levels of IFN- $\gamma$ among the groups were not significantly altered $\left(* \mathrm{P}<0.05,{ }^{* *} \mathrm{P}<0.01 ; \mathrm{n}=8-11\right.$ for each group).

allergic asthma responses, including eosinophilic lung inflammation, mucus hypersecretion and AHR upon suboptimal allergen challenge in the airway. Importantly, skin AD lesions were directly related to the development of enhanced airway responses. These findings were accompanied by a heightened systemic Th2 immune status as increased serum IgE and IgG1 and increased Th2 cytokine production by peripheral immune cells could be seen in the $\operatorname{Tg}(+)$ mice with AD.

IL-13 is a Th2 cytokine that has a prominent role in the pathogenesis of allergic asthma. In the present study, even though the IL-13 transgene was expressed selectively in the skin, increased levels of IL-13 could be found in the serum samples of $\operatorname{Tg}(+)$ mice as compared to $\operatorname{Tg}(-)$ mice. Thus it is essential to determine whether systemic IL-13 was responsible for the generation of enhanced asthmatic responses in these mice. Our analyses showed that although the serum IL-13 levels were comparable, only $\operatorname{Tg}(+)$ mice that developed $\mathrm{AD}$ had enhanced allergic responses to Ova challenge, whereas $\operatorname{Tg}(+)$ mice without $\mathrm{AD}$ did not (Figure 3), suggesting that serum IL-13 levels were not critical for the atopic march. On the other hand, when TSLP signaling was interrupted by deletion of TSLPR, the asthma phenotype in the $\operatorname{Tg}(+)$ mice was significantly dampened, indicating that TSLP signaling was critical in the atopic march in this system.

It has been reported that intradermal administration of recombinant TSLP promoted a systemic Th2 response, although its effects on atopic march was not examined ${ }^{23}$. In our study, the levels of TSLP were significantly increased in the $\mathrm{AD}$ skin lesions, higher in the acute $\mathrm{AD}$ than those in the chronic $\mathrm{AD}$, suggesting that TSLP may play a vital role in initiating systemic Th2 immunity favorable for the development of atopic march. Indeed, when TSLP signaling was blocked by genetic deletion of TSLPR, IL-13 $\mathrm{Tg}(+)$ mice showed greatly attenuated dermal inflammatory responses and reduced clinical AD scores, although the difference was not readily seen in later more severe chronic AD. Furthermore, $\operatorname{Tg}(+)$ mice deficient in TSLPR exhibited significantly diminished capability of mounting a rigorous lung inflammation and AHR upon Ova challenge. These changes in the skin and in the airway were in parallel with reduced systemic Th2 immune responses, including reduced IgE and Ovaspecific IgG1 and reduced Th2 cytokine production by peripheral immune cells. These findings indicate that TSLP signaling is important for the early development of $\mathrm{AD}$ and critical in triggering the atopic march, possibly through promoting peripheral lymphocyte production of Th2 cytokines IL- 4 and IL-13, which are critical for the differentiation of Th2 cells and for the tissue responses to allergen stimulation.

Increased levels of TSLP in the lesional skin of IL-13-induced AD were described previously ${ }^{17}$. Further analysis in this study showed that this increase was more prominent in the acute phase than in the chronic phase (Figure 4a). A critical role of TSLP signaling in IL-13induced $\mathrm{AD}$ and increased susceptibility to allergen stimulation was demonstrated in the experiments using mice with TSLPR null mutation. Unexpectedly, we could not detect any elevation in the TSLP in 




(d)

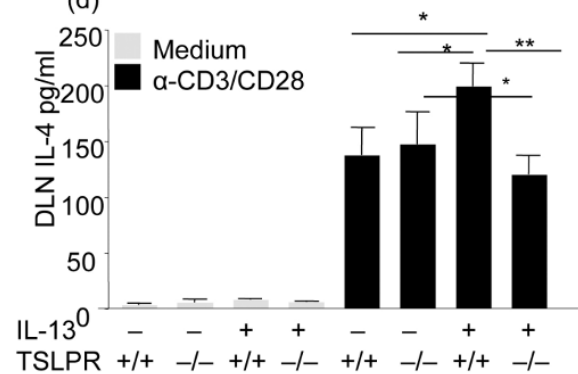

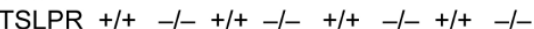

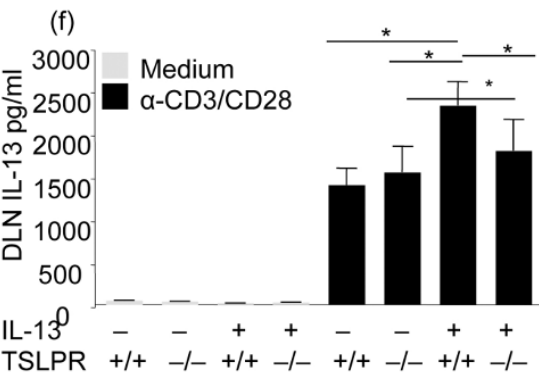

(h)

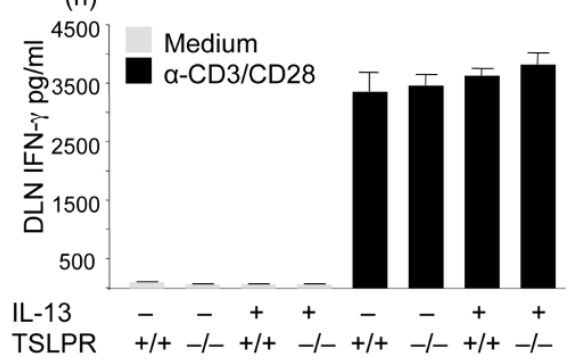

(b)



(c)

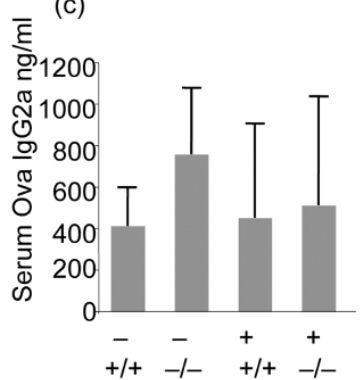

(e)

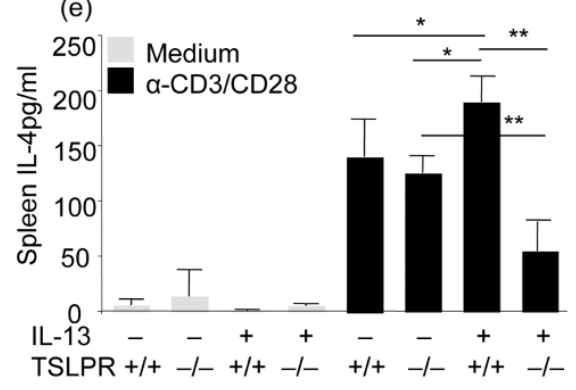

(g)

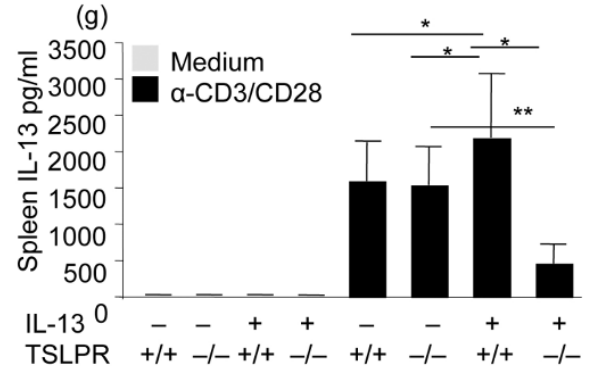

(i)

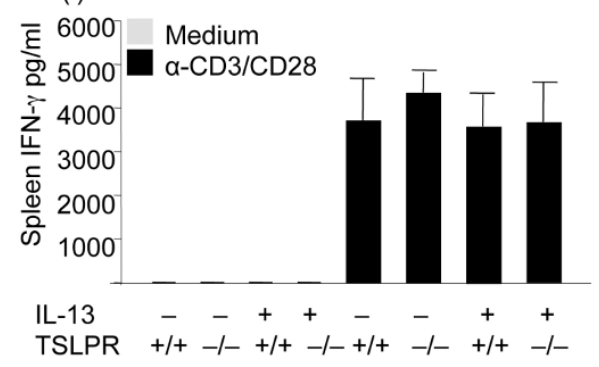

Figure $8 \mid$ Alterations of systemic Th2 immune responses to Ova allergen in $\operatorname{Tg}(+)$ mice with TSLPR deficiency. After sensitization and challenge by Ova, serum samples and lymphocytes from $\operatorname{Tg}(-)$ and $\operatorname{Tg}(+)$ mice with $\operatorname{TSLPR}(+/+)$ or $\operatorname{TSLPR}(-/-)$ were harvested and evaluated. (a) Serum total IgE levels were significantly reduced in the $\operatorname{Tg}(+) / \operatorname{TSLPR}(-/-)$ mice compared to the $\operatorname{Tg}(+) / \mathrm{TSLPR}(+/+)$ mice; (b) Serum levels of Ova-specific IgG1; (c) Serum Ova-specific IgG2a. For evaluation of cytokine production CD4+ cells from spleen and lymphocytes from cutaneous draining lymph nodes were isolated and activated by $\alpha$-CD3/CD28 for 3 days or medium as control. Cytokines in the supernatants were measured by ELISA. (d, e) IL- 4 levels; (f, g) IL-13 levels; and (h, i) IFN- $\gamma$ levels. ( $\mathrm{n}=6-7$ for each group; ${ }^{*} \mathrm{P}<0.05,{ }^{* *} \mathrm{P}<0.01$ ).

the blood circulation even at the time when IL-13 $\mathrm{Tg}(+)$ mice with acute AD showed peak levels of TSLP in the skin. The reason for this is unclear. In a study with MC903 (a low calcemic analogue of vitamin D3) induced $\mathrm{AD}$, Zhang et al. found that the increase of serum TSLP peaked on day 4 after stimulation but significantly reduced by day $22^{14}$. In two studies by Demehri et al. on mutant mice deficient in Notch signaling molecules and on K14-TSLP transgenic mice, high levels of TSLP were found in the serum samples of these mice with peak values seen in young mice, but significantly lower levels in adult mice $^{13,24}$. Thus, in these AD models there seems an optimal time period of TSLP expression by keratinocytes and release into the serum in younger mice or in early stimulation. As a product of keratinocytes, particularly in disease status, TSLP is known to be able to activate dendritic cells in situ and subsequently leading to allergic inflammation that is not limited to the skin ${ }^{11}$. Thus it is possible that
TSLP produced in the lesional skin of IL-13-induced AD stimulates DCs, which then migrate to draining lymph nodes and lead to systemic Th2 activation without changes in TSLP levels in the serum. However, the exact mechanism remains to be investigated. In addition, the expression patterns of TSLP in the skin of $\operatorname{Tg}(-)$ mice and in $\operatorname{Tg}(+)$ mice with acute and chronic AD in our study are consistent with some of the above observations. We speculate that the keratinocytes producing TSLP in the early AD are robust and responsive and have high capacity in producing inflammatory cytokines. However, at the later chronic stage, many of the keratinocytes may have been damaged resulting in reduced capacity to produce cytokines. Furthermore, deletion of TSLPR did not affect the IL-13 transgene expression in the skin nor the serum levels of IL-13 in $\operatorname{Tg}(+)$ mice, suggesting that TSLP signaling, not IL-13 per se, is critical in atopic dermatitis and atopic march in this model. 
In this study we chose to use a less than optimal protocol for Ova allergen induced allergic asthma responses. After the usual Ova sensitization, the mice were challenged through the airway with Ova 2 times, instead of 3 times used in usual protocols ${ }^{18}$. As seen in this study this protocol induces in normal mice a low degree airway inflammation and no enhanced AHR. However, under this condition IL-13 $\mathrm{Tg}(+)$ mice with AD displayed full-blown airway inflammation and enhanced AHR, suggesting increased susceptibility to allergen stimulation in these mice.

Previous studies showed that TSLP signaling is required to mount a normal $\mathrm{CD} 4+\mathrm{T}$ cell-mediated inflammatory response, and TSLPR-deficient mice (on Balb/c genetic background) failed to develop Th2 inflammatory lung response to inhaled antigen ${ }^{18}$. In this study, we consistently found that the $\operatorname{Tg}(-) / \operatorname{TSLPR}(+/+)$ and $\operatorname{Tg}(-) / \operatorname{TSLPR}(-/-)$ mice (C57BL/6 background) exhibited similar low levels of inflammatory responses in the lung upon suboptimal Ova challenge (Figure 7). This slight discrepancy between the two studies is likely due to differences in the genetic background of the mice used and in the challenge protocols in the studies.

Taken together, our studies clearly demonstrated that dermal expression of Th2 cytokine IL-13 not only induces atopic dermatitis but also predisposes to increased susceptibility to allergen-induced allergic asthma; the onset of atopic dermatitis is important for the development of atopic march; and by promoting a systemic Th2 environment the TSLP signaling is critical in the pathogenesis of IL-13-induced AD and in the atopic march.

\section{Methods}

Animals. The externally inducible skin-specific IL-13 transgenic mice (K5-tTA-IL$13(+)$ or simply $\operatorname{Tg}(+)$ mice) on C57BL/6 genetic background were generated by our laboratory as previously described ${ }^{17}$. To control the expression of IL-13 specifically and inducibly in the skin, Doxycycline (Dox) was added to the drinking water $(1 \mathrm{mg} / \mathrm{ml})$ to suppress tTA binding to its target and to keep the IL-13 transgene off, starting from breeding until the K5-tTA-IL-13 mice were six weeks old. The experiments were initiated by withdrawing Dox from the drinking water to activate the IL-13 transgene. In all experiments, $\operatorname{Tg}(-)$ littermate controls received the same amount of Dox or no Dox for the same length of time. The TSLPR gene null mice were a kind gift from Dr. Warren Leonard from NIH as described previously ${ }^{25}$. These mice on C57BL/6 genetic background were crossbred with the K5-tTA mice and TRE-Tight-IL-13 mice, both of which were on C57BL/ 6 background. The genotype of the K5-tTA-IL-13 mice was determined as described previously ${ }^{17}$. The genotype of the TSLP receptor null mice was determined using three PCR primers in one reaction: primer A, 5' -AACCTCTCCCACAA GAAGTCCAGAAGT-3'; Neo primer, $5^{\prime}$-ATCGCCTTCTATCGCCTTCTT-3'; and primer B,

5'-AGACTTTACCTGATTCCTGCCTTG-3'. Primers A and B amplify a 250-bp segment of the endogenous TSLPR gene. The Neo primer and primer B identify the targeted gene and give a 650 -bp product ${ }^{25}$. The offspring with genotypes K5-tTAIL13/TSLPR $(+/+)$ (or simply $\operatorname{Tg}(+) /$ TSLPR $(+/+)$ ) and K5-tTA-IL13/TSLPR $(-/-)$ (or simply $\operatorname{Tg}(+) / \operatorname{TSLPR}(-/-)$ ) were compared in the experiments. All procedures involving animals in this study were approved by the Johns Hopkins University Institutional Animal Care and Use Committee (IACUC).

\section{Ova allergen sensitization and challenge and assessment of allergic asthmatic} responses. K5-tTA-IL-13 (Tg) (+) mice that developed AD carrying wild type or null mutation of TSLPR and $\operatorname{Tg}(-)$ mice on C57BL/6 genetic background were used. The induction of IL-13 expression and AD disease was initiated by withdrawing Dox from the drinking water for all experimental groups, which were at similar age. The allergen sensitization and challenge protocol was started at 10 weeks of induction and by which time, the $\operatorname{Tg}(+)$ mice had an $\mathrm{AD}$ clinical score of about 2 . To test whether there were enhanced allergic asthma responses, we utilized a modified Ova challenge protocol with less strenuous stimulation with slight modification ${ }^{18}$. After initial sensitization with i.p. injection of Ova $(100 \mu \mathrm{g})$ with Alum (2 mg) (Sigma Chemicals) in $100 \mu \mathrm{l}$ PBS on day 0 and day 7, the mice were intranasally (i.n.) challenged with $10 \mu \mathrm{g}$ Ova in $50 \mu \mathrm{l}$ PBS on days 21 and 22. For control groups, mice were i.p. injected with Alum only and given PBS at challenge (Figure 1a). Mice were assessed for AHR one day after the last dose of Ova challenge (day 23) using invasive PFT for airway resistance $(\mathrm{R})\left(\mathrm{cmH}_{2} \mathrm{O} \bullet \mathrm{s} / \mathrm{ml}\right)$ and lung compliance $(\mathrm{C})\left(\mathrm{ml} / \mathrm{cmH}_{2} \mathrm{O}\right)$ using a small rodent PFT apparatus flexiVent (SCIREQ Inc., Montreal, Canada). Airway hyperresponsiveness (AHR) was also assessed by noninvasive whole body plethysmography (Buxco) in response to inhaled methacholine (Sigma), using enhanced pause (Penh) as an index of airway responsiveness ${ }^{26}$. BAL fluids and serum samples were collected from mice that underwent noninvasive PFT on day 24 . After lavage, lungs were excised completely from the chest cavity, inflated with $10 \%$ neutral buffered formalin (Fisher Scientific) and fixed in the same solution overnight at room temperature. Tissues were embedded in paraffin, sectioned at $5 \mu \mathrm{m}$, and stained with $\mathrm{H} \& \mathrm{E}$ and Alcian blue.

Clinical disease and itchy/scratching scores. $\operatorname{Tg}(+)$ and $\operatorname{Tg}(-)$ mice were examined for skin lesions 3 times per week and the clinical scores for disease severity were recorded as described with slight modifications ${ }^{17,21,27}$. Acute dermatitis was defined as occurring less than 10 weeks after the transgene induction with a clinical score $\leq 2$ and chronic $\mathrm{AD}$ was defined as occurring 10 weeks after induction with an $\mathrm{AD}$ score $>2$. The clinical manifestation of itching/scratching behavior of the mice was videotaped 30 minutes/time, twice a week at the same time each time. The scratching behavior was counted for hind limb scratching directed towards the dermatitis areas. One scratch was considered to be a lifting of the hind limb towards the dermatitis areas and then a replacing of the limb back to the floor, regardless of how many scratching strokes take place between those two movements as described previously with slight modification ${ }^{28}$.

Assessment of airway and lung tissue inflammation. BAL cellularity including total cell counts and cell differential were performed and lung tissue inflammation was assessed using the morphometric approaches that have been described ${ }^{26}$. Fifteen different images of H\&E-stained lung sections from 7 animals in each group were captured at high power on an Olympus BX50 microscopy (Olympus America, NY, USA). This was accomplished using a QImaging Retiga EXi Camera (from BioVision Technologies, Inc, Exton, PA) with iVision Software (from BioVision Technologies, Inc, Exton, PA). The infiltrating cells were counted in a $200 \times 200 \mu \mathrm{m}^{2}$ area of the bronchovascular bundles of randomly selected medium-sized airways. The data are presented as Mean \pm SEM of cells per high power field (HPF).

Preparation of skin protein extracts and measurement of cytokines. Protein samples from the skin were prepared as described previously ${ }^{17}$. Briefly, frozen skin tissues were placed in liquid nitrogen, crushed with a mortar and pestle and weighed. Triton X-100 $0.25 \%$ (wt/vol) in phosphate-buffered saline was added to the skin powder. The homogenate was stirred at $4{ }^{\circ} \mathrm{C}$ overnight and then centrifuged at $3000 \times \mathrm{g}$ for 15 minutes to remove debris. Supernatants were stored in small aliquots at $-80^{\circ} \mathrm{C}$ until assayed. All samples were normalized to the weight of the skin samples. Cytokines in the skin samples were determined using ELISA kits per the manufacturer's instructions (R\&D Systems, Minneapolis, MN).

Histology and immunohistochemistry (IHC) evaluation. After mice were killed, lesional and nonlesional skin was excised and fixed in neutral-buffered formalin at $4{ }^{\circ} \mathrm{C}$ overnight, embedded in paraffin, sectioned at $5 \mu \mathrm{m}$, and stained with hematoxylin \& eosin ( $\mathrm{H} \& \mathrm{E})$ and toluidine blue for histological analysis as described ${ }^{17}$. Immunohistochemistry assays were performed as previously described ${ }^{17}$. A rat antimouse major basic protein monoclonal antibody (a kind gift from Drs. Nancy and James J. Lee, Mayo Clinic, Scottsdale, AZ) was applied to stain for eosinophils. Similarly, for CD4+ cells, rat anti-CD4 monoclonal antibody (Santa Cruz Biotechnology Inc., Santa Cruz, CA) was applied at a $1: 100$ dilution $(1 \mu \mathrm{g} / \mathrm{ml})$ or rat anti-F4/80 antibody for evaluation of activated Langerhans cells and macrophages (Pan macrophage marker clone: BM8, 14-4801; eBioscience, San Diego, CA) at 1:100 dilution $(1 \mu \mathrm{g} / \mathrm{ml})$. Appropriate ABC Staining Systems were used to visualize the target proteins in the tissues (Santa Cruz Biotechnology).

Assessment of cytokine production by lymphocytes from draining lymph nodes and spleen. Splenic CD $4^{+}$T cells were isolated using anti-CD4 MACS MicroBeads in HBSS containing 5\% FCS and $2 \mathrm{mM}$ EDTA and positively selected on MS MACS separation columns (Miltenyi Biotec, Auburn, CA) according to the manufacturer's instructions. Lymphocytes from draining lymph nodes (inguinal, axillaries and subclavicle) and purified splenic CD4+ cells were cultured in complete RPMI 1640 medium containing 5\% FCS and activated using 96-well anti-CD3 plate (BD bioscience) plus anti-CD28 $(5 \mu \mathrm{g} / \mathrm{ml})$ for 3 days. Supernatants were collected and examined for cytokine production.

Measurement of cytokines, chemokines, and immunoglobulins. Cytokines and chemokines in the skin, BAL fluid and cell culture supernatant samples were measured using ELISA kits according to the manufacturer's instructions (R\&D Systems, Minneapolis, MN).

Statistical analysis. Student's $t$-test was used to determine the significance of difference between two groups and one-way ANOVA was used for comparison among multiple groups. All data were expressed as Mean \pm SEM. A difference of $\mathrm{P}<0.05$ was considered statistically significant.

1. Laughter, D., Istvan, J. A., Tofte, S. J. \& Hanifin, J. M. The prevalence of atopic dermatitis in Oregon schoolchildren. J Am Acad Dermatol 43, 649-655 (2000).

2. Ker, J. \& Hartert, T. V. The atopic march: what's the evidence? Ann Allergy Asthma Immunol 103, 282-289 (2009).

3. Kulig, M. et al. Natural course of sensitization to food and inhalant allergens during the first 6 years of life. J Allergy Clin Immunol 103, 1173-1179 (1999).

4. Ricci, G. et al. Long-term follow-up of atopic dermatitis: retrospective analysis of related risk factors and association with concomitant allergic diseases. J Am Acad Dermatol 55, 765-771 (2006). 
5. Martinez, F. D. et al. Asthma and wheezing in the first six years of life. The Group Health Medical Associates. N Engl J Med 332, 133-138 (1995).

6. Spergel, J. M. From atopic dermatitis to asthma: the atopic march. Ann Allergy Asthma Immunol 105, 99-106; quiz 107-109, 117 (2010).

7. Gustafsson, D., Sjoberg, O. \& Foucard, T. Development of allergies and asthma in infants and young children with atopic dermatitis-a prospective follow-up to 7 years of age. Allergy 55, 240-245 (2000).

8. Wuthrich, B. \& Schmid-Grendelmeier, P. The atopic eczema/dermatitis syndrome. Epidemiology, natural course, and immunology of the IgE-associated ("extrinsic") and the nonallergic ("intrinsic") AEDS. J Investig Allergol Clin Immunol 13, 1-5 (2003).

9. Spergel, J. M. et al. Epicutaneous sensitization with protein antigen induces localized allergic dermatitis and hyperresponsiveness to methacholine after single exposure to aerosolized antigen in mice. J Clin Invest 101, 1614-1622 (1998).

10. He, R. et al. Exaggerated IL-17 response to epicutaneous sensitization mediates airway inflammation in the absence of IL-4 and IL-13. J Allergy Clin Immunol 124, 761-770 e761 (2009).

11. Liu, Y. J. Thymic stromal lymphopoietin: master switch for allergic inflammation. J Exp Med 203, 269-273 (2006).

12. Lee, E. B. et al. Increased serum thymic stromal lymphopoietin in children with atopic dermatitis. Pediatr Allergy Immunol 21, e457-460 (2010).

13. Demehri, S., Morimoto, M., Holtzman, M. J. \& Kopan, R. Skin-derived TSLP triggers progression from epidermal-barrier defects to asthma. PLoS Biol 7 e1000067 (2009)

14. Zhang, Z. et al. Thymic stromal lymphopoietin overproduced by keratinocytes in mouse skin aggravates experimental asthma. Proc Natl Acad Sci U S A 106, 15361541 (2009).

15. Hamid, Q. et al. In vivo expression of IL-12 and IL-13 in atopic dermatitis J Allergy Clin Immunol 98, 225-231 (1996).

16. Jeong, C. W. et al. Differential in vivo cytokine mRNA expression in lesional skin of intrinsic vs. extrinsic atopic dermatitis patients using semiquantitative RT-PCR. Clin Exp Allergy 33, 1717-1724 (2003).

17. Zheng, T. et al. Transgenic expression of interleukin-13 in the skin induces a pruritic dermatitis and skin remodeling. J Invest Dermatol 129, 742-751 (2009).

18. Al-Shami, A., Spolski, R., Kelly, J., Keane-Myers, A. \& Leonard, W. J. A role for TSLP in the development of inflammation in an asthma model. J Exp Med 202, 829-839 (2005).

19. Yoo, J. et al. Spontaneous atopic dermatitis in mice expressing an inducible thymic stromal lymphopoietin transgene specifically in the skin. J Exp Med 202, 541-549 (2005).

20. Zhou, B. et al. Thymic stromal lymphopoietin as a key initiator of allergic airway inflammation in mice. Nat Immunol 6, 1047-1053 (2005).

21. Akei, H. S. et al. Epicutaneous aeroallergen exposure induces systemic TH2 immunity that predisposes to allergic nasal responses. J Allergy Clin Immunol 118, 62-69 (2006).
22. Strid, J., Hourihane, J., Kimber, I., Callard, R. \& Strobel, S. Disruption of the stratum corneum allows potent epicutaneous immunization with protein antigens resulting in a dominant systemic Th2 response. Eur J Immunol 34, 2100 2109 (2004).

23. Jessup, H. K. et al. Intradermal administration of thymic stromal lymphopoietin induces a $\mathrm{T}$ cell- and eosinophil-dependent systemic $\mathrm{Th} 2$ inflammatory response. J Immunol 181, 4311-4319 (2008).

24. Demehri, S. et al. Notch-deficient skin induces a lethal systemic Blymphoproliferative disorder by secreting TSLP, a sentinel for epidermal integrity. PLoS Biol 6, e123 (2008).

25. Al-Shami, A. et al. A role for thymic stromal lymphopoietin in CD4(+) T cell development. J Exp Med 200, 159-168 (2004).

26. Zhu, Z. et al. Acidic mammalian chitinase in asthmatic Th2 inflammation and IL-13 pathway activation. Science 304, 1678-1682 (2004).

27. Leung, D. Y. et al. Thymopentin therapy reduces the clinical severity of atopic dermatitis. J Allergy Clin Immunol 85, 927-933 (1990).

28. Shimada, S. G., Shimada, K. A. \& Collins, J. G. Scratching behavior in mice induced by the proteinase-activated receptor-2 agonist, SLIGRL-NH2. Eur J Pharmacol 530, 281-283 (2006).

\section{Acknowledgments}

This work was supported by NIH grants R01AI075025 to T.Z. and R01HL079349 to Z.Z. The authors would like to thank Dr. Warren Leonard of NIH for providing the TSLP receptor deficient mice.

\section{Author contributions}

ZZ participated in study design, contributed reagents, performed experiments, analyzed data, and reviewed and edited the manuscript; MHO performed experiments and analyzed data; JHY performed experiments and analyzed data; YJL participated in experimental design and data analyses, contributed reagents and edited the manuscript; TZ conceived the study, designed the experiments, analyzed the data and wrote the manuscript.

\section{Additional information}

Supplementary Information accompanies this paper at http://www.nature.com/ scientificreports

Competing financial interests: The authors declare no competing financial interests.

License: This work is licensed under a Creative Commons

Attribution-NonCommercial-NoDerivative Works 3.0 Unported License. To view a copy of this license, visit http://creativecommons.org/licenses/by-nc-nd/3.0/

How to cite this article: Zhu, Z., Oh, M., Yu, J., Liu, Y.J. \& Zheng, T. The Role of TSLP in IL-13-Induced Atopic March. Sci. Rep. 1, 23; DOI:10.1038/srep00023 (2011). 